IZA DP No. 9196

The Effect of Family Size on Education: New Evidence from China's One Child Policy

Laura M. Argys

Susan L. Averett

July 2015 


\title{
The Effect of Family Size on Education: New Evidence from China's One Child Policy
}

\author{
Laura M. Argys \\ University of Colorado Denver \\ and IZA \\ Susan L. Averett \\ Lafayette College \\ and IZA
}

Discussion Paper No. 9196
July 2015

IZA
P.O. Box 7240
53072 Bonn
Germany

Phone: +49-228-3894-0

Fax: +49-228-3894-180

E-mail: iza@iza.org

\begin{abstract}
Any opinions expressed here are those of the author(s) and not those of IZA. Research published in this series may include views on policy, but the institute itself takes no institutional policy positions. The IZA research network is committed to the IZA Guiding Principles of Research Integrity.

The Institute for the Study of Labor (IZA) in Bonn is a local and virtual international research center and a place of communication between science, politics and business. IZA is an independent nonprofit organization supported by Deutsche Post Foundation. The center is associated with the University of Bonn and offers a stimulating research environment through its international network, workshops and conferences, data service, project support, research visits and doctoral program. IZA engages in (i) original and internationally competitive research in all fields of labor economics, (ii) development of policy concepts, and (iii) dissemination of research results and concepts to the interested public.
\end{abstract}

IZA Discussion Papers often represent preliminary work and are circulated to encourage discussion. Citation of such a paper should account for its provisional character. A revised version may be available directly from the author. 


\title{
ABSTRACT \\ The Effect of Family Size on Education: New Evidence from China's One Child Policy ${ }^{*}$
}

\begin{abstract}
Social scientists theorize that the inverse relationship between socio-economic status and family size represents a trade-off between the quality and quantity of children. Evaluating this hypothesis empirically requires addressing the simultaneity of the quality and quantity decisions. Researchers have used the unanticipated birth of twins as exogenous variation in family size or the sex composition of the first two children as an instrument for family size with mixed results. We exploit a different source of exogenous variation in family size. The One Child Policy (OCP) in China dramatically reduced Chinese fertility and we examine how the OCP has affected the educational attainment of Chinese migrants to the U.S. Using data from the American Community Survey (2009-2012) and a difference-in-differences strategy our results support the quality-quantity tradeoff theory. We find that education increased more for Chinese migrants born after the OCP than their counterparts from other East Asian countries.
\end{abstract}

JEL Classification: $\quad 121, \mathrm{~J} 18$

Keywords: education, migration, quality-quantity tradeoff, family size, One Child Policy

Corresponding author:

Laura M. Argys

Department of Economics

University of Colorado Denver

Campus Box 173364

PO Box 173364

Denver, CO 80217-3364

USA

E-mail: laura.argys@ucdenver.edu

The authors thank Deborah Cobb-Clark, Daniel Hamermesh, Jessica Hardie, David Ribar, Massimiliano Tani and Yang Wang for helpful comments on an earlier draft. 


\section{Introduction}

Both across and within countries, social scientists have noted the inverse relationship between family income or socio-economic status and family size. Although economic theory labels a good for which demand falls as income rises as 'inferior,' economists have devoted a great deal of energy to developing models that explain this association between income and children that do not rely on the assumption that children are inferior goods. The dominant theory in this debate is the 'quantity-quality tradeoff' (Becker and Lewis, 1973; Becker and Tomes, 1976) and a number of researchers have provided empirical evidence of the existence of such a trade-off in either education or health (e.g. Lee, 2008; Li et al., 2008; Rosenzweig and Zhang, 2009; Ponczek and Souza, 2012) although other researchers find little empirical evidence of such a tradeoff (e.g. Angrist et al., 2010; Millimet and Wang, 2011; Peters et al., 2014).

The quantity-quality tradeoff suggests that parents maximize utility by allocating time across a number of uses in combination with making expenditures on a variety of goods. Consumption choices include the demand for 'child services' comprised of both the number of children and their quality. Child quality may be defined across a number of dimensions including educational attainment and achievement, social adeptness, health, and successful adult outcomes such as earnings, and/or stable family formation. Regardless of the measure of child quality, the general consensus is that its production at the family level can be both goods- and time-intensive. In the original development of the model, Becker and Tomes (1976) suggest that both the quantity and quality of children enter parents' utility function. Inherent in the decisions to produce and consume these two child characteristics, Becker and Tomes explicitly recognize that the price of child quality is increasing in child quantity and vice versa. More specifically, a decision to increase the number of children is more expensive the greater is the chosen level of 
child quality. This theory provides a plausible explanation for the negative relationship between income and the number of children and it has been extensively tested for its ability to explain the relationships between family size and investments in children.

A difficulty in addressing the quantity-quality tradeoff empirically is accounting for the simultaneity of the quality and quantity decisions. For example, if sets of parents differ in their preferences for child quality, those parents who are more concerned about quality would prefer to have fewer children but invest more in them rather than having many low-quality children. In this situation, a spurious correlation between quality and number of children exists due to unobserved heterogeneity across households.

Estimates of the causal relationship between quality and quantity requires exogenous variation in one or the other. Researchers have addressed this in a number of ways, most typically by using the unanticipated birth of twins as exogenous variation in family size or using the sex composition of the first two children as an instrument for family size (Angrist et al., 2010; Li et al., 2008; Rosenzweig and Zhang, 2009; Millimet and Wang, 2011; Ponczek and Souza, 2012). Both of these approaches exploit plausibly exogenous variation in family size, however each has its limitations. The twins strategy can only provide estimates of the effect of having two children instead of one under the assumption that there is nothing inherently different about having twins. To conduct analyses with larger sample sizes that are not limited to twins, many researchers have relied on sex-preferences and the randomly assigned sex of the first child or first two children to generate exogenous incentives for the birth of a second or third child. For example, Lee (2008) uses data from South Korea and estimates models that use the sex of the first child as an instrument for family size. The validity of this instrument relies on the consistent finding that parents in many Asian countries prefer sons to daughters and if the first 
child is not a son are more likely to have a second child. In these countries, the sex of the first child should be a good predictor for the probability of having a second child or even for the total number of children. Lee reports evidence suggesting a quantity-quality tradeoff. This strategy may not be appropriate in countries where sex-selective abortion or other mechanisms for altering sex ratios at birth are commonplace because the sex of the first child is not random. The sex ratio at birth for most countries lies between 102 and 107 (CIA, 2014). However, China and India are among a handful of countries in which the sex ratio at birth is above 110 suggesting that the sex of the first child may not random for some individuals.

In this paper, we exploit a different source of exogenous variation in family size to shed additional light on the quantity-quality tradeoff. The One Child Policy in China (hereafter referred to as the OCP) has had a dramatic impact on Chinese fertility. China's total fertility rate, which can be thought of as the mean number of children born per woman, decreased from 2.9 in 1979 to 1.7 in 2004 (Hesketh et al., 2005). ${ }^{1}$ We examine how the OCP has affected the educational attainment of Chinese migrants to the U.S. This strategy allows us to examine the impact of an exogenous reduction in family size in an individual's family of origin (resulting from the OCP) on that individual's educational attainment in adulthood. In order to interpret the impact of the OCP on education as a quantity-quality effect it must be the case that Chinese migrants to the U.S. who were born after the OCP experienced a larger drop in their fertility than did migrants from other countries in the control group. An analysis focused on migrants is novel, and although it provides estimates only for a select sample of individuals, this strategy provides a test of the quantity-quality tradeoff in the absence of fertility restrictions on children as they move into adulthood themselves.

\footnotetext{
${ }^{1}$ The total fertility rate was falling before the official start of the OCP and some scholars argue that reduced fertility in China was due in large part to socioeconomic changes and not the OCP per se (Cai, 2010).
} 
The paper proceeds as follows. We first describe the OCP and discuss research that has used it to identify the quantity-quality tradeoff using data from China. We then discuss our data and empirical strategy and make the case for examining the quantity-quality tradeoff using data from Chinese immigrants. Finally we describe our results, present sensitivity analyses and discuss the implications of our findings.

\section{Background}

\section{Brief overview of China's OCP}

China's OCP was introduced in 1979 and was intended to be a short-term measure that would help the country move to a small family culture (Hesketh et al., 2005). At the time, the Chinese government saw smaller families and lower population growth as essential components of a plan to increase economic growth. The OCP was actually the culmination of a series of policies aimed at creating a small family culture voluntarily. Starting in 1970, Chinese couples were urged to have only two children. Beginning in 1972 the Chinese government instituted a policy aimed at delayed childbearing with longer spacing between births - the 'Later, Longer, Fewer' policy (Settles et al., 2013). This policy urged couples to have children when they were older, space them further apart and have fewer of them. Economic incentives were provided to families who spaced the birth of their children at least four years apart (Islam and Smith, 2015). As Qian (2009) argues, if this four-year birth spacing law was enforced the one-child policy should be binding for those born in 1976 and after. In our empirical work, we define the transition period as 1970-1978 and the post-OCP period as beyond 1979. We do, however, test the sensitivity of our results to these cutoffs. 
The OCP is enforced at the local level by a system of rewards, penalties and fines that can vary widely. The OCP also depends on virtually universal access to contraception and abortion. In 2001, 87 percent of all married women in China reported using contraception compared to about 33 percent in most developing countries (Hesketh et al., 2005).

The OCP only fully applies to a subset of the Chinese population. Ethnic Han Chinese (who comprise about 92 percent of China's population) living in urban areas or who are government employees must strictly adhere to the OCP and within this group the policy is firmly enforced with only few exceptions (Islam and Smith, 2015). Exceptions are allowed if a first born child is disabled, the parents work in highly dangerous occupations or both parents are themselves from one-child families. In rural China, where the majority of the population still resides, a second child is sometimes allowed after five years, particularly if the first is a girl as son preference is strong in China (Hesketh et al., 2005; Islam and Smith, 2015).

Empirical evidence of a quantity-quality tradeoff using the OCP as exogenous variation in family size

We are aware of only three studies that use the OCP to attempt to identify a quantity-quality trade-off using Chinese data. Qian (2009) studies exogenous changes in family size caused by the relaxation of China's OCP. She estimates the causal effect of family size on the school enrollment of the first child. Using regional and time variation in China's relaxation of its OCP for rural families; (i.e. if the first child is a girl and/or parents were themselves only children, the policy was relaxed and couples could have a second child—sometimes this is referred to as the 1.5 rule since those with a girl first child would typically try for a boy) as well as multiple births to estimate the effects of increased family size on child education. Her analysis suggests that the 
relaxation of the OCP increased the school enrollment rate of first-born children and she argues that this occurs because of economies of scale in schooling; e.g. children from the same family can share textbooks and clothing.

In contrast to the findings of Qian (2009) both Liu (2014) and Rosenzweig and Zhang (2009) find support for the quantity-quality tradeoff in China. Specifically, Rosenzweig and Zhang (2009) use Chinese twin births and the relaxation of the OCP as their measure of exogenous family size and find that educational attainment declines in response to the birth of an additional sibling.

Finally, Liu (2014) uses a similar identification strategy as Qian (2009) and Rosenzweig and Zhang (2009) but in addition to the eligibility for an exception to the OCP as an instrument for number of children, Liu also uses fines for unsanctioned births and an interaction between the two as exogenous determinants of fertility. He finds that more children in a family significantly reduces child height thus supporting the quantity-quality tradeoff. Liu also examines education outcomes and finds only weak evidence that increased quantity lowers quality as measured by educational attainment.

The mixed results described above do not provide conclusive evidence that reduced fertility causes additional education in China particularly when examining educational outcomes beyond secondary schooling. Changes in child quality in response to increases in child quantity in this context may result from the fact that decisions about educational attainment are made in the context of expectations about marriage and fertility. These other considerations are likely to be affected by the OCP, and are expected to be particularly salient for educational decisions made for female children. With the OCP still in place, it is plausible that increased educational attainment is in response to the anticipation of reduced fertility for the child. In particular, since 
children born in the OCP environment may, as adults, be subject to the same policy, their parents may base their education investment decisions for these children on an expectation of their child's reduced fertility. For example, parents who have a daughter may expect that she would only have one child and hence parents would invest heavily in her education knowing that she would at most, have only one child. In contrast, we analyze a sample of Chinese born men and women who migrated to the United States and we observe their educational attainment in an environment where their fertility as an adult is unconstrained by policy.

\section{Data and Method}

We use data from the American Community Survey for the years 2009 to $2012 .^{2}$ These data are well-suited for our analysis for several reasons. First, these data contain information on country of birth, date of migration and citizenship status as well as education, age and year of birth thus facilitating our identification method. Second, the large sample allows us to focus on the countries of interest. Our econometric model is as follows:

(1) $y_{\text {ict }}=\alpha+$ Post $_{t} \gamma_{1}+C_{c} \gamma_{2}+\left(\right.$ Post $\left._{t}^{*} C_{c}\right) \gamma_{3}+X_{\text {ict }} \gamma_{4}+\varepsilon_{\text {ict }}$

Where $y_{i c t}$ is years of education for person $i$ born in country $c$ in year $t$. Post $t_{t}$ is a binary variable equal to 1 if the individual was born after the OCP became effective; i.e. after 1979. Because our data spans the years 2009 to 2012, in our sample individuals born after the OCP are at most 32 years old. We limit our sample to those aged 24 to 40 years to allow sufficient time for individuals to have completed a college education. Those aged 24 to 32 are born in the post one child period (i.e. 1980 and beyond) while those aged 30 (born in 1978 and interviewed in 2009) to 40 were born in the transitional period prior to the formal introduction of the OCP. Thus, in

\footnotetext{
${ }^{2}$ These data are available from IPUMS USA data: https://usa.ipums.org/usa/.
} 
our baseline model individuals in our sample were born between the years 1969 to 1988 . We limit ourselves to a relatively narrow age range to avoid confounding effects of the OCP with changes in migrant cohort quality (Borjas, 1985). Age and age squared control for birth cohort and allow us to control for changes in educational attainment across cohorts. $\mathrm{C}_{\mathrm{c}}$ is a binary variable which takes the value of one if the individual was born in China and 0 if they were born in our control group countries. We omit those who are born abroad of American parents because their parents would not be subject to the exogenous shock to family size created by the OCP. $X_{\text {ict }}$ is a vector of individual-specific controls including age, marital status, years in the U.S. and English speaking ability. We also control for citizen status-distinguishing between those who are foreign born naturalized citizens and those who are foreign born but not citizens. The coefficient of primary interest, $\gamma_{3}$, is the effect of being born in China after the implementation of the OCP.

As noted above, the OCP was formally introduced in 1979 after a transition period which was marked by a call to voluntarily delay marriage and reduce family size with the Later, Longer, Fewer policy. Because this transition period was markedly different from the previous decade, we limit our pre-OCP time frame to those born between 1970 and 1978, and the post OCP period to those born after 1979. Because the policy became effective in 1979 we exclude those born in 1979 from our sample.

Our control group consists of migrants born in other East Asian countries who were not subject to the OCP. This includes individuals born in Hong Kong, Taiwan, Japan, and S. Korea. ${ }^{3}$ In our specification checks, we also introduce India as a control group as we detail below. An

\footnotetext{
${ }^{3}$ Even with the detailed place of birth codes, we are unable to tell which Koreans migrated from South versus North Korea. However, it is very likely that most of our Korean migrants are from South Korea as noted here: http://www.migrationpolicy.org/article/north-korea-understanding-migration-and-closed-country. In addition, although Mongolia and Macau are also East Asian countries, we did not have any immigrants from those countries in our sample. A few observations ( $\mathrm{N}=144, .39 \%$ of sample) were listed as East Asia, not specified and our results are not at all sensitive to their inclusion so they are retained in the sample.
} 
appropriate control group should be similar to the treatment group in terms of observable characteristics and also exhibit similar pre-treatment trends in the outcome variable(s) of interest (i.e. educational attainment). Figures 1 and 2 depict average educational attainment for individuals by birth year for our treatment and control groups. For both males and females the treatment and control groups exhibit similar trends for individuals born prior to the OCP in 1979, although the levels are higher for other East Asians compared to Chinese migrants. Despite these similarities we test the sensitivity of our estimates by directly controlling for pre-trends. The post-1979 trends diverge dramatically.

\section{Results}

\section{Descriptive Statistics and Baseline Model}

Tables 1 and 2 present the means of our outcome and control variables by treatment and control group status before and after the OCP for men and women. We conduct all of our analyses separately by gender. The first two columns of Table 1 are the means for Chinese migrants for those born in the pre-OCP era and those born post-OCP. The following three pairs of columns report pre- and post- OCP means for different control groups. Comparing Column 1 to Column 3 allows us to compare the pre-treatment characteristics of Chinese to other East Asian migrants. The treatment and control groups are similar in the pre-period although Chinese men have been in the U.S. for a shorter time than their other East Asian counterparts and have somewhat lower education levels and are less likely to be U.S. citizens. In columns 5 and 6 of Table 1, we present the sample means for Indian men since we use them as an additional control group in some of our later analyses. Comparing Columns 1 and 5, we see that male migrants from India tend to 
have slightly more education but have been in the U.S. for fewer years and are less likely to be separated, divorced or widowed than male Chinese migrants. Finally, in the last two columns of Table 1, we present the means for East Asian immigrants excluding those from Japan since we also use this sample as an additional control group. This last group is the most similar to the sample of Chinese migrants except that they have been in the U.S. longer and are more likely to be citizens when compared to Chinese male migrants.

Table 2 presents similar comparisons of sample means for women. Again, although similar in many respects, we do note some important differences in the pre-period between the treatment group (Chinese migrants) and the control group of other East Asian migrants. In particular, female Chinese immigrants have been in the U.S. for fewer years, they are less likely to be citizens and they are more likely to be married than their East Asian counterparts. When we consider Indians as the control group, we see that female Chinese migrants and female Indian migrants are quite similar along all dimensions except for education and marital status (i.e. Column 1 to Column 5). Comparing Chinese migrants to those from East Asia without Japanese migrants, we see that the Chinese female migrants have been in the U.S. a shorter time period, are less likely to be citizens and more likely to be married than this group.

From Tables 1 and 2, we can calculate unadjusted difference-in-differences estimates which foreshadow the parametric results to come. We see that on average Chinese men born after 1979 have .14 more years of education than Chinese men born before the OCP. In comparison, East Asian migrant men born in post OCP have .61 fewer years of education on average. This leads to a difference in differences estimate of .75 larger increase in education for Chinese vs. East Asian male migrants. A similar calculation for women reveals a smaller education advantage of .26 which still favors Chinese-born women. 
Table 3 presents the results of our baseline estimation of equation 1 above. For each sex, we estimate three models. The first is a model with no controls which allows us to calculate the statistical significance of the non-parametric difference-in-differences estimates calculated from Tables 1 and 2, the second model adds a quadratic in age and in the final model we add controls for citizenship status, years in the U.S. and marital status. Because OLS standard errors are known to be biased downward in this type of application, all standard errors are bootstrapped.

The results in Columns 1 and 2 of Table 3 indicate that compared to other East Asian migrants, men and women who migrated from China in the post-OCP period obtained significantly more education. The effect is larger for men than for women and is statistically significant at the 1 percent level for both groups. Adding age to the specification (in Columns 3 and 4) does not change the point estimates appreciably although we see the expected effect of age on education — as migrants age they obtain more education but at a decreasing rate. The addition of our other set of covariates in Columns 5 and 6 leave the point estimates and significance levels essentially unchanged. Years in the U.S. has a negative and significant effect on education for men but is positive and significant for women. Being a U.S. citizen has a negative effect on years of education for both men and women but does not reach conventional levels of significance for men. Single women complete more education while married men have an education advantage.

Our results reveal that the OCP exerted a positive and significant impact on educational attainment of Chinese migrants to the U.S. compared to other East Asian migrants in the same time period. The magnitudes are meaningful in that, for men, the post-OCP increase of .75 of a year of education substantially narrows the education gap between migrants from China and their 
other East Asian migrant counterparts. ${ }^{4}$ In the next section, we conduct a number of specification checks including controlling for possible differences in pre-trends across our treatment and control groups, allowing for differences in behavioral responses in the pre- and post- periods, and constructing a wider window for the OCP to account for the Later, Longer, Fewer policy. In addition, we extend our analyses to groups of migrants restricted by the timing of and age at migration. We also conduct a number of falsification tests that alter the timing and location of the adoption of the OCP.

\section{Specification checks}

The key assumption underlying any difference-in-differences strategy is that the outcome of interest in the treatment and the control groups would follow the same trend over time if not for the treatment. Specifically, in our case, we would be concerned if Chinese immigrants born before the OCP already displayed a trend in their educational attainment which was significantly different from that of our control group (other East Asian migrants) prior to the implementation of the OCP. In that instance, it would be difficult to conclusively assign the change in our outcome variable to the policy change itself. To examine whether our estimates are confounded by differences in pre-treatment trends we control for these trends directly in the model. In specifications shown in Table 4 we re-estimate the models presented in Table 3 but include interactions between being born in China and each birth-year in our sample prior to 1979 . We find that these interactions are rarely individually significant (and not jointly significant) and our point estimates on the difference in differences coefficient are quite similar for women. Although smaller for men than in Table 3, the estimates remain statistically significant at the 1

\footnotetext{
${ }^{4}$ This statement results from a comparison of the coefficients $\gamma_{2}(-.894)$ and $\gamma_{3}(.747)$.
} 
percent level for both groups, indicating that pre-existing trends in educational attainment are not driving our results.

Researchers have expressed concern that if explanatory variables have different effects in the pre- and post-treatment periods, difference-in-differences models may attribute these differences to the treatment. To test the degree to which these post-treatment behavioral effects might be important, we allow the effect of all individual characteristics to vary for the post-OCP cohorts. These models, in which all explanatory variables are interacted with the post-OCP indicator, are shown in Table 5. There are some differences in the impact of personal characteristics for those born before and after the OCP particularly for men. Most importantly, the overall difference-in-differences estimators are remarkably consistent with our earlier results. This gives us confidence that our results are not driven by changes in the effects of the explanatory variables on education over time.

Another important specification check concerns the timing of the OCP. As noted earlier, the precursor to the OCP was the Later, Longer, Fewer policy and as Qian (2009) notes, one can effectively think of the OCP as beginning in 1976. To see how sensitive our results are to the changing social norms regarding family size that were being implemented during this time period, we drop individuals from our sample who were born in 1976, 1977, 1978 or 1979 resulting in a comparison of those born between 1970-1975 (pre-OCP cohorts) to the post-OCP cohorts born after 1979. The results from this change in specification are presented in Table 6 . The results are remarkably similar to the baseline models in Table 3 in magnitude and statistical significance.

An additional concern is the possible impact of the Cultural Revolution in China which ended just before the OCP was enacted. Starting in 1966 and lasting for about a decade, this 
movement had a tremendous impact on the educational system in China (Andreas, 2009). In the early months of the Cultural Revolution, schools and universities were closed. Primary and middle schools later gradually reopened, but all colleges and universities were closed until 1970, and most universities did not reopen until 1972. University entrance exams were cancelled and not reinstated until 1977. Because our outcome of interest is education, the timing of the Cultural Revolution, ending just as the Later, Longer, Fewer policy was starting, might confound our results. To be sure that this is not the case, we estimate our model on a sample of those born after 1970 so that their schooling experience in China (before migration) would not have been influenced by the Cultural Revolution. Our treatment remains the OCP. These results, shown in Table 7, make clear that the Cultural Revolution is not driving our findings. In particular, we still see a positive and significant impact of the OCP on the education of Chinese migrants to the U.S.

Immigration rules have changed over time in the U.S. To be sure that our educational differences are not driven by differing policies on who can migrate to the U.S. we re-estimate the baseline models shown in Table 3, restricting our sample to those who have migrated to the U.S. within the past 10 years. Our justification for this specification is that these more recent migrants face approximately the same immigration policies. These results are presented in Table 8 and are quite consistent with those in Table 3.

Because the theoretical explanation of the quantity-quality tradeoff involves investment decisions made by parents, we also estimate models limiting the sample to those who migrated between the ages of 10 and 17 (inclusive). By examining outcomes for individuals who migrated after the age of 10 we attempt to exclude individuals whose parents left China to have more children than allowed under the OCP. Individuals who migrated before the age of 18 were likely 
to be accompanied by their parents. This increases the likelihood that parents were influential in decisions regarding educational attainment.

Estimates for the samples migrating between the ages of 10 and 17 are presented in Table 9. For men, we still see that Chinese male migrants who were born after the OCP obtain more education than their East Asian counterparts born after the OCP. However, we no longer see statistically significant results for women in this sample and the point estimates are now negative with larger standard errors (we would expect larger standard errors because the sample sizes are substantially smaller). These results suggest that Chinese women who come to the U.S. as children may have parents who recognize that their daughter's fertility is unconstrained and hence do not invest as much in their education.

\section{Falsification Tests}

In this section of our paper, we present several falsification tests. The purpose of these tests is to bolster our claim that the OCP is driving our results. We first start with a model where we falsify the timing of the OCP. Specifically, we drop from our sample anyone born after 1973 and we classify those born after 1969 as born in our false OCP time frame. Similar to our preferred specification, we want to avoid confounding the effects of our false OCP with changes in cohort quality thus we now limit our age range to those under the age of 50 . The results of this falsification test are presented in Table 10. We see that our point estimates are small, slightly negative and not statistically significant. We interpret these precise estimates as indicating that there is no effect on education of being born after 1969. These results give us confidence that our earlier results are capturing the effect of smaller family size on educational investment in an environment where fertility is not constrained. 
The next falsification check we consider is an examination of India versus the other East Asian countries. India was experiencing declining fertility at the same time that China was but never adopted a formal OCP. In Table 11, we treat India as the "treatment” country experiencing the adoption of an OCP in 1979 and other East Asian countries as the control group. Chinese migrants are not included in this analysis. Interestingly, we find that in this case, Indians (the 'falsely' treated group) have significantly higher education than do other East Asians migrants in the post-OCP period. The effect sizes are smaller (about half the size of those when China is the treatment group) and significant.

The results in Table 11 lead us to consider India as an alternate control group and we present these results in Table 12. Despite the fact that both India and China were experiencing declining fertility at the same time, we see a significant positive effect of the OCP on the educational attainment of Chinese migrants compared to Indian migrants in the post OCP period. The point estimates are smaller but still statistically significant indicating that although China and India each experienced declining fertility over the relevant periods, differences in educational attainment for cohorts born before and after the introduction of the OCP in China are larger than differences in educational attainment for the same cohorts in India. This suggests that a sharper break in fertility associated with the OCP in China translated into significant increases in education among Chinese-born men and women who migrated to the U.S.

In other specification checks not shown in this paper, we also further restricted our age range to those aged 27 and above to allow the youngest in our sample to have completed graduate school. These results remain positive and significant for men although slightly smaller in magnitude. For women, we find a smaller coefficient which is not statistically significant. Finally, to address possible concerns that Japan is strikingly different from China and therefore 
not appropriate for inclusion in the control group, we eliminate Japanese migrants from the sample. The estimates from this exercise are remarkably similar to our baseline model shown in Tables 3. These results are available from the authors upon request.

\section{Conclusion}

We use exogenous variation in fertility caused by China's OCP to test the quantity-quality trade off among Chinese migrants to the U.S. Our approach is novel in that we focus on migrants from China to the U.S. Using data from four years of the American Community Survey, we show that males born after the OCP who migrated from China obtain more education than their counter parts who migrated from other east Asian countries without an OCP. In our preferred specification they obtain about 5 percent more education than our control group. Our results are robust to numerous specification checks.

Because our empirical strategy involves estimating educational attainment for (young) adults born in China who migrated to the US, there are two possible concerns with our empirical strategy if we hope to interpret our estimates as indicators of a causal effect of family size on child quality for Chinese children. One is that the estimates may be biased due to endogeneity. The possible source of the endogeneity arises from the fact that there are three decisions that are potentially made simultaneously. Parents (or young adults, depending on the age at the time of migration) are making two decisions to invest in human capital - migration and educational attainment. These decisions are layered over an environment that might restrict fertility. Our strategy addresses these concerns in two ways. By conducting difference-in-differences analysis, we use other East Asian migrants as a control group. To the extent that migration alters or is correlated with the education decision, our estimates should net out this bias. In studies that 
examine the impact of quantity of children on quality using the OCP as an exogenous shift in family size for children who remain in China, education decisions for adolescents are made under an environment in which these children themselves are likely to be restricted to having only one child. Chinese adolescents who migrate to the US are under no such constraint. In that regard, these estimates represent the impact of number of siblings on education in an unconstrained fertility environment.

Another possible concern is that parents who choose to migrate to the US after the OCP may be those most interested in having additional children. However to the extent that increased fertility dampens the demand for education, the bias introduced by this sample selection should work against finding significant increases in education for post OCP birth cohorts.

As noted earlier, our identification strategy is predicated on the assumption that the OCP would be binding for those who do not migrate. However, we cannot tell whether our migrants came from an urban or a rural area in China thus we cannot know for sure if they would be subject to the OCP had they not left China. Additionally, we cannot control for parental education nor can we control for birth order. Black et al., 2005 found evidence that the quantityquality tradeoff disappeared when controlling for birth order using a sample of Norwegians. However, given that our identification strategy suggests that these migrants do not have siblings since their parents were subject to the OCP, this is not likely to be a primary concern for our analysis. 


\section{References}

Andreas, Joel. (2009). Rise of the Red Engineers: The Cultural Revolution and the Origins of China's New Class. Stanford: Stanford University Press. p. 164.ISBN 978-0804760782.

Angrist, J., Lavy, V. and A. Schlosser. (2010). Multiple experiments for the causal link between the quantity and quality of children. Journal of Labor Economics, 28(4), 773-824.

Becker, Gary S. and H. Gregg Lewis. (1973) . On the interaction between the quantity and quality of children. The Journal of Political Economy, 81(2) Part 2, Mar.-Apr.,S279-S288.

Becker, G. S. and N. Tomes. (1976). Child Endowments and the Quantity and Quality of Children. Journal of Political Economy, 84(4):S143-S162.

Black, Sandra E., Paul G. Devereux, and Kjell G. Salvanes. (2005). The More the Merrier? The Effect of Family Composition on Children's Education. Quarterly Journal of Economics, 120(2): $669-700$.

Borjas, George J. (1985). Assimilation, Changes in Cohort Quality, and the Earnings of Immigrants. Journal of Labor Economics, 3(4): 463-89.

Cai, Yong. (2010). China's Below-Replacement Fertility: Government Policy or Socioeconomic Development? Population and Development Review 36(3)3: 419-40.

CIA. (2014). The World Factbook._Available at: https://www.cia.gov/library/publications/theworld-factbook/fields/2018.html. Last accessed on July 17, 2014.

Hesketh, T., Lu, L. and Z.W. Xing. (2005). The effect of China's one-child family policy after 25 years. New England Journal of Medicine, 353(11), 1171-1176.

Islam, A. and R. Smyth. (2015). Do Fertility Control Policies Affect Health in Old Age?

Evidence From China's One-child Experiment. Health economics. 24(5), 601-616.

Lee, J. (2008). Sibling size and investment in children's education: An Asian instrument. Journal of Population Economics, 21(4), 855-875.

Li, H., Zhang, J. and Y. Zhu. (2008). The quantity-quality trade-off of children in a developing country: Identification using Chinese twins. Demography, 45(1), 223-243.

Liu, H. (2014). The quality-quantity trade-off: evidence from the relaxation of China's one-child policy. Journal of Population Economics, 27(2), 565-602.

Millimet,D. L. and L. Wang, (2011). Is the quantity-quality trade-off a trade-off for all, none, or some? Economic Development and Cultural Change, 60(1), 155-195. 
Peters, C., D. I. Rees and R. Hernández-Julián, R. (2013). The trade-off between family size and child health in rural Bangladesh. Eastern Economic Journal, 40(1), 71-95.

Ponczek, V. and A.P. Souza. (2012). New evidence of the causal effect of family size on child quality in a developing country. Journal of Human Resources, 47(1), 64-106.

Qian, N. (2009). Quantity-quality and the one child policy: The only-child disadvantage in school enrollment in rural China (No. w14973). National Bureau of Economic Research.

Rosenzweig, M. R. and J. Zhang. (2009). Do population control policies induce more human capital investment? Twins, birth weight and China's “one-child” policy. The Review of Economic Studies, 76(3), 1149-1174.

Settles, B. H., X. Sheng, Y. Zang, and J. Zhao. (2013). The one-child policy and its impact on Chinese families. In International Handbook of Chinese Families (pp. 627-646). Springer New York. 


\section{Figure 1. Male Education Levels by Birth Year and Country of Birth}

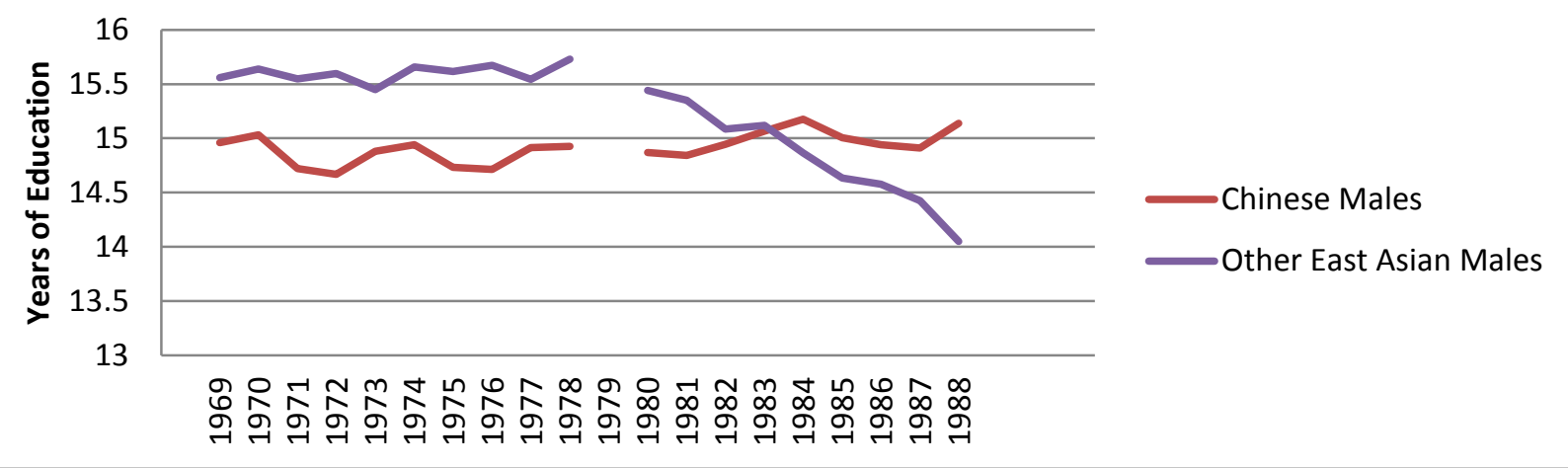




\section{Figure 2. Female Education Levels by Birth Year and Country of Birth}

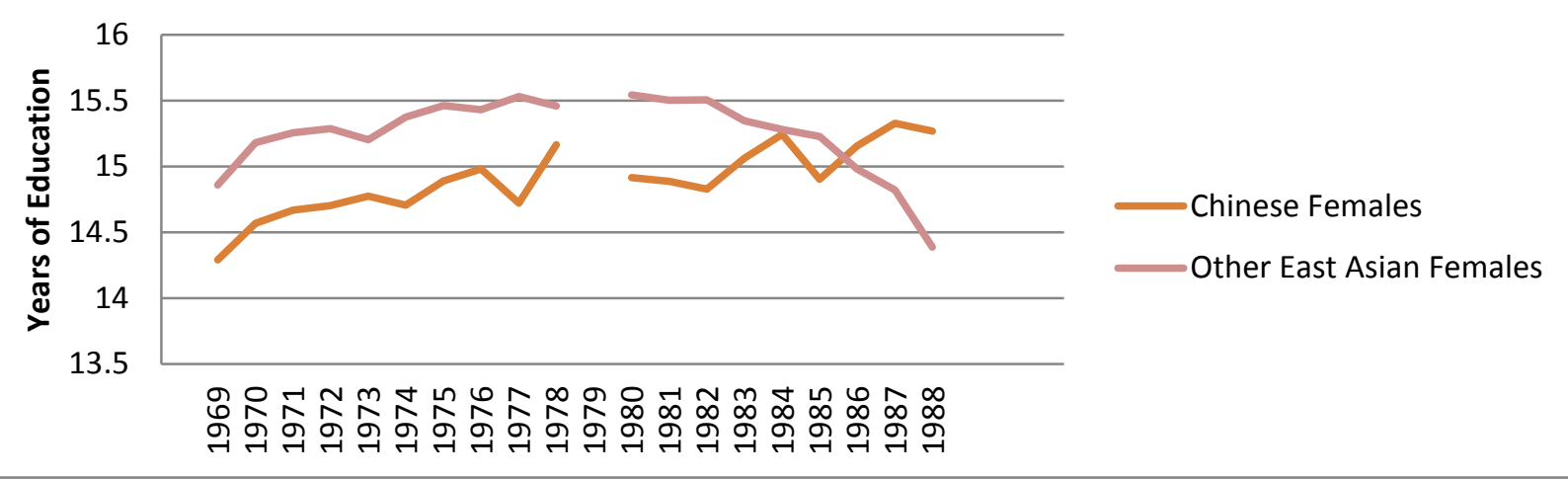


Table 1: Sample means - American Community Survey 2009-2012: Male Immigrants Age 24-40

\begin{tabular}{|c|c|c|c|c|c|c|c|c|}
\hline \multirow[b]{2}{*}{ Variable } & \multicolumn{2}{|c|}{ China } & \multicolumn{2}{|c|}{ East Asia } & \multicolumn{2}{|c|}{ India } & \multicolumn{2}{|c|}{ East Asia, No Japan } \\
\hline & Pre & Post & Pre & Post & Pre & Post & Pre & Post \\
\hline \multirow[t]{2}{*}{ Years of education completed } & 14.85 & 14.99 & 15.61 & 15.00 & 16.12 & 15.94 & 15.61 & 14.97 \\
\hline & $(2.81)$ & $(2.41)$ & $(1.78)$ & $(1.84)$ & $(1.52)$ & $(1.56)$ & $(1.77)$ & $(1.85)$ \\
\hline \multirow[t]{2}{*}{ Age } & 36.14 & 27.10 & 36.09 & 27.59 & 35.53 & 27.80 & 36.08 & 27.58 \\
\hline & $(2.82)$ & $(2.30)$ & $(2.79)$ & $(2.31)$ & $(2.78)$ & $(2.28)$ & $(2.80)$ & $(2.31)$ \\
\hline \multirow[t]{2}{*}{ Years in the United States } & 12.85 & 7.98 & 17.04 & 13.45 & 10.73 & 6.63 & 18.33 & 14.10 \\
\hline & $(7.72)$ & (7.11) & $(11.21)$ & $(9.35)$ & $(7.05)$ & $(6.32)$ & $(10.92)$ & $(9.25)$ \\
\hline U.S. citizen & 0.37 & 0.30 & 0.50 & 0.51 & 0.31 & 0.20 & 0.57 & 0.55 \\
\hline Married & 0.82 & 0.35 & 0.70 & 0.23 & 0.90 & 0.48 & 0.69 & 0.22 \\
\hline Separated/divorced or widowed & 0.04 & 0.02 & 0.04 & 0.02 & 0.02 & 0.01 & 0.04 & 0.02 \\
\hline \multirow[t]{2}{*}{ Year of birth } & 1974.26 & 1983.69 & 1974.25 & 1983.07 & 1974.83 & 1982.92 & 1974.26 & 1983.06 \\
\hline & $(2.83)$ & $(2.36)$ & $(2.84)$ & $(2.29)$ & $(2.78)$ & $(2.20)$ & $(2.84)$ & $(2.29)$ \\
\hline Observations & 4102 & 2853 & 5439 & 3079 & 8802 & 5088 & 4612 & 2734 \\
\hline
\end{tabular}

Standard deviations of continuous variables in parentheses

East Asia includes Japan, S. Korea, Hong Kong and Taiwan 
Table 2: Sample means - American Community Survey 2009-2012: Female Immigrants Age 24-40

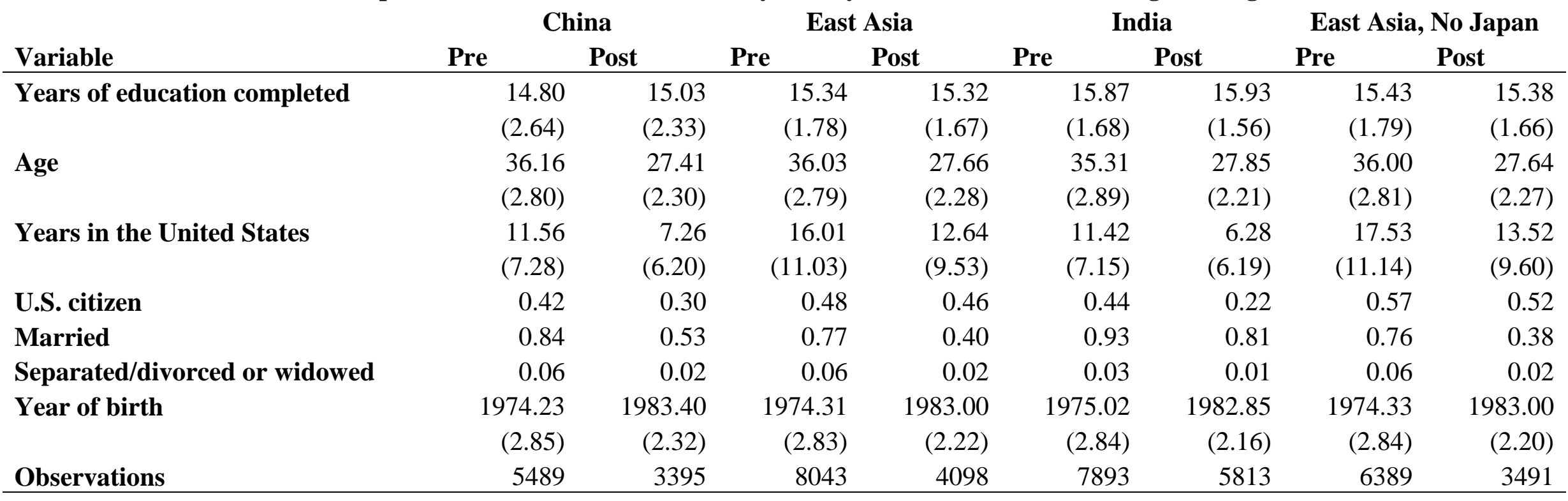

Standard deviations of continuous variables in parentheses

East Asia includes Japan, S. Korea, Hong Kong and Taiwan 
Table 3: Determinants of Education - China versus other East Asian Countries

\begin{tabular}{|c|c|c|c|c|c|c|}
\hline VARIABLES & $\begin{array}{l}\text { (1) } \\
\text { males }\end{array}$ & $\begin{array}{c}(2) \\
\text { females }\end{array}$ & $\begin{array}{c}\text { (3) } \\
\text { males }\end{array}$ & $\begin{array}{c}\text { (4) } \\
\text { females }\end{array}$ & $\begin{array}{l}\text { (5) } \\
\text { males }\end{array}$ & $\begin{array}{c}(6) \\
\text { females }\end{array}$ \\
\hline Born post-OCP*born in China & $\begin{array}{c}0.745^{* * *} \\
(0.059)\end{array}$ & $\begin{array}{c}0.263^{* * *} \\
(0.048)\end{array}$ & $\begin{array}{c}0.784^{* * *} \\
(0.059)\end{array}$ & $\begin{array}{c}0.269 * * * \\
(0.047)\end{array}$ & $\begin{array}{c}0.747 * * * \\
(0.057)\end{array}$ & $\begin{array}{c}0.264^{* * *} \\
(0.045)\end{array}$ \\
\hline Born in China & $\begin{array}{c}-0.751^{* * *} \\
(0.048)\end{array}$ & $\begin{array}{c}-0.549 * * * \\
(0.038)\end{array}$ & $\begin{array}{c}-0.748 * * * \\
(0.048)\end{array}$ & $\begin{array}{c}-0.542 * * * \\
(0.038)\end{array}$ & $\begin{array}{c}-0.894 * * * \\
(0.045)\end{array}$ & $\begin{array}{c}-0.466 * * * \\
(0.039)\end{array}$ \\
\hline Born post-OCP & $\begin{array}{c}-0.610 * * * \\
(0.045)\end{array}$ & $\begin{array}{l}-0.023 \\
(0.033)\end{array}$ & $\begin{array}{c}-0.354 * * * \\
(0.081)\end{array}$ & $\begin{array}{c}-0.061 \\
(0.054)\end{array}$ & $\begin{array}{c}-0.301 * * * \\
(0.081)\end{array}$ & $\begin{array}{l}-0.051 \\
(0.054)\end{array}$ \\
\hline Age & & & $\begin{array}{c}0.402 * * * \\
(0.060)\end{array}$ & $\begin{array}{c}0.420 * * * \\
(0.044)\end{array}$ & $\begin{array}{c}0.373 * * * \\
(0.058)\end{array}$ & $\begin{array}{c}0.495^{* * *} \\
(0.045)\end{array}$ \\
\hline Age squared & & & $\begin{array}{c}-0.006^{* * * *} \\
(0.001)\end{array}$ & $\begin{array}{c}-0.007 * * * \\
(0.001)\end{array}$ & $\begin{array}{c}-0.005^{* * *} \\
(0.001)\end{array}$ & $\begin{array}{c}-0.008^{* * *} \\
(0.001)\end{array}$ \\
\hline Years in the United States & & & & & $\begin{array}{c}-0.023 * * * \\
(0.003)\end{array}$ & $\begin{array}{c}0.015^{* * *} \\
(0.002)\end{array}$ \\
\hline Not U.S. citizen & & & & & $\begin{array}{l}-0.100 \\
(0.064)\end{array}$ & $\begin{array}{c}-0.311^{* * *} \\
(0.042)\end{array}$ \\
\hline Married & & & & & $\begin{array}{c}0.278 * * * \\
(0.047)\end{array}$ & $\begin{array}{c}-0.268 * * * \\
(0.039)\end{array}$ \\
\hline Separated/divorced or widowed & & & & & $\begin{array}{c}-0.789 * * * \\
(0.127)\end{array}$ & $\begin{array}{c}-0.911 * * * \\
(0.093)\end{array}$ \\
\hline Constant & $\begin{array}{c}15.605 * * * \\
(0.024)\end{array}$ & $\begin{array}{c}15.344 * * * \\
(0.019)\end{array}$ & $\begin{array}{c}8.717 * * * \\
(1.011)\end{array}$ & $\begin{array}{c}8.874 * * * \\
(0.716)\end{array}$ & $\begin{array}{c}9.397 * * * \\
(0.968)\end{array}$ & $\begin{array}{c}7.626 * * * \\
(0.741)\end{array}$ \\
\hline Observations & 15,264 & 20,784 & 15,264 & 20,784 & 15,264 & 20,784 \\
\hline R-squared & 0.021 & 0.012 & 0.024 & 0.017 & 0.047 & 0.028 \\
\hline
\end{tabular}

Bootstrapped standard errors in parentheses. Dependent variable is years of education.

East Asia includes S. Korea, Japan, Taiwan and Hong Kong.

$$
\text { *** } \mathrm{p}<0.01, * * \mathrm{p}<0.05, * \mathrm{p}<0.1
$$


Table 4: Determinants of Education - China Versus Other East Asian Countries Controlling for Pre-trends

\begin{tabular}{|c|c|c|c|c|c|c|}
\hline VARIABLES & $\begin{array}{c}(1) \\
\text { males }\end{array}$ & $\begin{array}{c}(2) \\
\text { females }\end{array}$ & $\begin{array}{c}(3) \\
\text { males }\end{array}$ & $\begin{array}{c}(4) \\
\text { females }\end{array}$ & $\begin{array}{c}(5) \\
\text { males }\end{array}$ & $\begin{array}{c}(6) \\
\text { females }\end{array}$ \\
\hline Born post-OCP*born in China & $\begin{array}{c}0.568 * * * \\
(0.131)\end{array}$ & $\begin{array}{c}0.303^{* * *} \\
(0.094)\end{array}$ & $\begin{array}{c}0.571^{* * *} \\
(0.132)\end{array}$ & $\begin{array}{c}0.353^{* * *} \\
(0.095)\end{array}$ & $\begin{array}{c}0.515^{* * *} \\
(0.131)\end{array}$ & $\begin{array}{c}0.345^{* * *} \\
(0.095)\end{array}$ \\
\hline Born in China & $\begin{array}{c}-0.573 * * * \\
(0.127)\end{array}$ & $\begin{array}{c}-0.589 * * * \\
(0.099)\end{array}$ & $\begin{array}{c}-0.534 * * * \\
(0.128)\end{array}$ & $\begin{array}{c}-0.625^{* * * *} \\
(0.100)\end{array}$ & $\begin{array}{c}-0.661 * * * \\
(0.129)\end{array}$ & $\begin{array}{c}-0.547 * * * \\
(0.100)\end{array}$ \\
\hline Born post-OCP & $\begin{array}{c}-0.610 * * * \\
(0.045)\end{array}$ & $\begin{array}{l}-0.023 \\
(0.033)\end{array}$ & $\begin{array}{c}-0.340 * * * \\
(0.083)\end{array}$ & $\begin{array}{c}-0.069 \\
(0.052)\end{array}$ & $\begin{array}{c}-0.275^{* * *} \\
(0.082)\end{array}$ & $\begin{array}{c}-0.062 \\
(0.052)\end{array}$ \\
\hline Born in China * 1970 & $\begin{array}{c}0.004 \\
(0.242)\end{array}$ & $\begin{array}{c}-0.184 \\
(0.166)\end{array}$ & $\begin{array}{c}0.053 \\
(0.249)\end{array}$ & $\begin{array}{c}0.090 \\
(0.171)\end{array}$ & $\begin{array}{c}-0.004 \\
(0.249)\end{array}$ & $\begin{array}{c}0.117 \\
(0.173)\end{array}$ \\
\hline Born in China * 1971 & $\begin{array}{c}-0.306 \\
(0.213)\end{array}$ & $\begin{array}{c}-0.083 \\
(0.160)\end{array}$ & $\begin{array}{l}-0.279 \\
(0.219)\end{array}$ & $\begin{array}{c}0.148 \\
(0.165)\end{array}$ & $\begin{array}{l}-0.344 \\
(0.225)\end{array}$ & $\begin{array}{c}0.155 \\
(0.162)\end{array}$ \\
\hline Born in China * 1972 & $\begin{array}{c}-0.361 * \\
(0.191)\end{array}$ & $\begin{array}{c}-0.049 \\
(0.168)\end{array}$ & $\begin{array}{c}-0.354^{*} \\
(0.195)\end{array}$ & $\begin{array}{c}0.137 \\
(0.169)\end{array}$ & $\begin{array}{c}-0.404^{* *} \\
(0.191)\end{array}$ & $\begin{array}{c}0.141 \\
(0.169)\end{array}$ \\
\hline Born in China * 1973 & $\begin{array}{l}-0.147 \\
(0.162)\end{array}$ & $\begin{array}{c}0.025 \\
(0.120)\end{array}$ & $\begin{array}{c}-0.190 \\
(0.165)\end{array}$ & $\begin{array}{c}0.119 \\
(0.123)\end{array}$ & $\begin{array}{l}-0.206 \\
(0.161)\end{array}$ & $\begin{array}{c}0.125 \\
(0.124)\end{array}$ \\
\hline Born in China * 1974 & $\begin{array}{l}-0.087 \\
(0.185)\end{array}$ & $\begin{array}{l}-0.046 \\
(0.130)\end{array}$ & $\begin{array}{c}-0.156 \\
(0.189)\end{array}$ & $\begin{array}{l}-0.021 \\
(0.131)\end{array}$ & $\begin{array}{l}-0.155 \\
(0.189)\end{array}$ & $\begin{array}{l}-0.026 \\
(0.131)\end{array}$ \\
\hline Born in China * 1975 & $\begin{array}{l}-0.295 \\
(0.185)\end{array}$ & $\begin{array}{c}0.139 \\
(0.159)\end{array}$ & $\begin{array}{c}-0.382 * * \\
(0.190)\end{array}$ & $\begin{array}{c}0.104 \\
(0.159)\end{array}$ & $\begin{array}{c}-0.390^{* *} \\
(0.188)\end{array}$ & $\begin{array}{c}0.085 \\
(0.159)\end{array}$ \\
\hline Born in China * 1976 & $\begin{array}{c}-0.316^{*} \\
(0.171)\end{array}$ & $\begin{array}{c}0.230 \\
(0.149)\end{array}$ & $\begin{array}{c}-0.408 * * \\
(0.175)\end{array}$ & $\begin{array}{c}0.151 \\
(0.147)\end{array}$ & $\begin{array}{c}-0.399 * * \\
(0.177)\end{array}$ & $\begin{array}{c}0.125 \\
(0.149)\end{array}$ \\
\hline Born in China * 1977 & $\begin{array}{l}-0.115 \\
(0.213)\end{array}$ & $\begin{array}{c}-0.029 \\
(0.160)\end{array}$ & $\begin{array}{c}-0.201 \\
(0.214)\end{array}$ & $\begin{array}{c}-0.142 \\
(0.161)\end{array}$ & $\begin{array}{l}-0.203 \\
(0.212)\end{array}$ & $\begin{array}{c}-0.150 \\
(0.155)\end{array}$ \\
\hline Born in China * 1978 & $\begin{array}{c}-0.104 \\
(0.190)\end{array}$ & $\begin{array}{c}0.413 * * * \\
(0.134)\end{array}$ & $\begin{array}{c}-0.171 \\
(0.192)\end{array}$ & $\begin{array}{c}0.278 * * \\
(0.133)\end{array}$ & $\begin{array}{l}-0.180 \\
(0.185)\end{array}$ & $\begin{array}{c}0.276^{* *} \\
(0.130)\end{array}$ \\
\hline Observations & 15,264 & 20,784 & 15,264 & 20,784 & 15,264 & 20,784 \\
\hline R-squared & 0.022 & 0.014 & 0.025 & 0.018 & 0.048 & 0.028 \\
\hline
\end{tabular}

Bootstrapped standard errors in parentheses. Dependent variable is years of education.

East Asia includes S. Korea, Japan, Taiwan and Hong Kong.

*** $\mathrm{p}<0.01,{ }^{* *} \mathrm{p}<0.05,{ }^{*} \mathrm{p}<0.1$. These models include the same controls as listed in the corresponding columns of table 3 . 
Table 5: Determinants of Education - China vs. Other East Asian Countries - Differential Effects of Covariates in Post-Period

\begin{tabular}{|c|c|c|c|c|}
\hline VARIABLES & $\begin{array}{c}(1) \\
\text { males }\end{array}$ & $\begin{array}{c}(2) \\
\text { females }\end{array}$ & $\begin{array}{c}(3) \\
\text { males }\end{array}$ & $\begin{array}{c}(4) \\
\text { females }\end{array}$ \\
\hline Born post-OCP*born in China & $\begin{array}{c}0.789 * * * \\
(0.059)\end{array}$ & $\begin{array}{c}0.268 * * * \\
(0.048)\end{array}$ & $\begin{array}{c}0.724^{* * *} \\
(0.058)\end{array}$ & $\begin{array}{c}0.203^{* * *} \\
(0.046)\end{array}$ \\
\hline Born in China & $\begin{array}{c}-0.750 * * * \\
(0.048)\end{array}$ & $\begin{array}{c}-0.541 * * * \\
(0.037)\end{array}$ & $\begin{array}{c}-0.889 * * * \\
(0.044)\end{array}$ & $\begin{array}{c}-0.454 * * * \\
(0.037)\end{array}$ \\
\hline Born post-OCP & $\begin{array}{c}-13.187^{* * * *} \\
(4.852)\end{array}$ & $\begin{array}{c}4.588 \\
(4.717)\end{array}$ & $\begin{array}{c}-14.678^{* * *} \\
(4.779)\end{array}$ & $\begin{array}{c}1.973 \\
(4.616)\end{array}$ \\
\hline Age & $\begin{array}{l}-0.066 \\
(0.207)\end{array}$ & $\begin{array}{c}0.722 * * * \\
(0.171)\end{array}$ & $\begin{array}{l}-0.100 \\
(0.197)\end{array}$ & $\begin{array}{c}0.682^{* * *} \\
(0.172)\end{array}$ \\
\hline Age squared & $\begin{array}{c}0.001 \\
(0.003)\end{array}$ & $\begin{array}{c}-0.011^{* * *} \\
(0.002)\end{array}$ & $\begin{array}{c}0.001 \\
(0.003)\end{array}$ & $\begin{array}{c}-0.010^{* * * *} \\
(0.002)\end{array}$ \\
\hline Years in the United States & & & $\begin{array}{c}-0.014 * * * \\
(0.004)\end{array}$ & $\begin{array}{c}0.023^{* * *} \\
(0.003)\end{array}$ \\
\hline U.S. citizen & & & $\begin{array}{c}-0.245^{* * * *} \\
(0.069)\end{array}$ & $\begin{array}{c}-0.360^{* * *} \\
(0.050)\end{array}$ \\
\hline Married & & & $\begin{array}{c}0.401 * * * \\
(0.049)\end{array}$ & $\begin{array}{c}-0.032 \\
(0.057)\end{array}$ \\
\hline Separated/divorced or widowed & & & $\begin{array}{c}-0.763^{* * *} \\
(0.134)\end{array}$ & $\begin{array}{c}-0.625 * * * \\
(0.105)\end{array}$ \\
\hline Age*born post OCP & $\begin{array}{l}0.791 * * \\
(0.319)\end{array}$ & $\begin{array}{l}-0.242 \\
(0.309)\end{array}$ & $\begin{array}{c}0.899 * * * \\
(0.314)\end{array}$ & $\begin{array}{l}-0.080 \\
(0.302)\end{array}$ \\
\hline Age squared* born post OCP & $\begin{array}{c}-0.012 * * \\
(0.005)\end{array}$ & $\begin{array}{c}0.003 \\
(0.005)\end{array}$ & $\begin{array}{c}-0.014 * * * \\
(0.005)\end{array}$ & $\begin{array}{c}0.001 \\
(0.005)\end{array}$ \\
\hline Years in the U.S.* born post OCP & & & $\begin{array}{c}-0.030 * * * \\
(0.005)\end{array}$ & $\begin{array}{c}-0.027^{* * *} \\
(0.005)\end{array}$ \\
\hline U.S. citizen* born post OCP & & & $\begin{array}{c}0.426^{* * *} \\
(0.110)\end{array}$ & $\begin{array}{c}0.203^{* *} \\
(0.081)\end{array}$ \\
\hline Married* born post OCP & & & $\begin{array}{c}-0.295 * * * \\
(0.074)\end{array}$ & $\begin{array}{c}-0.458 * * * \\
(0.074)\end{array}$ \\
\hline Separated/divorced/widowed* born post OCP & & & $\begin{array}{c}0.149 \\
(0.257)\end{array}$ & $\begin{array}{c}-0.774 * * * \\
(0.205)\end{array}$ \\
\hline Constant & $\begin{array}{c}17.056^{* * *} \\
(3.667)\end{array}$ & $\begin{array}{c}3.486 \\
(3.011)\end{array}$ & $\begin{array}{c}17.772^{* * *} \\
(3.490)\end{array}$ & $\begin{array}{c}4.127 \\
(3.024)\end{array}$ \\
\hline Observations & 15,264 & 20,784 & 15,264 & 20,784 \\
\hline R-squared & 0.024 & 0.017 & 0.050 & 0.031 \\
\hline
\end{tabular}

Bootstrapped standard errors in parentheses. Dependent variable is years of education.

East Asia includes S. Korea, Japan, Taiwan and Hong Kong. $\quad{ }^{* * *} \mathrm{p}<0.01,{ }^{* *} \mathrm{p}<0.05,{ }^{*} \mathrm{p}<0.1$ 
Table 6: Determinants of Education - China versus other East Asian Countries - Expanded Gap Accounting for Later, Longer

\begin{tabular}{|c|c|c|c|c|c|c|}
\hline \multicolumn{7}{|c|}{ Fewer Policy } \\
\hline VARIABLES & $\begin{array}{c}(1) \\
\text { males }\end{array}$ & $\begin{array}{c}(2) \\
\text { females }\end{array}$ & $\begin{array}{c}\text { (3) } \\
\text { Males }\end{array}$ & $\begin{array}{c}(4) \\
\text { females }\end{array}$ & $\begin{array}{c}(5) \\
\text { males }\end{array}$ & $\begin{array}{c}\text { (6) } \\
\text { females }\end{array}$ \\
\hline Born post-OCP*born in China & $\begin{array}{c}0.747 * * * \\
(0.068)\end{array}$ & $\begin{array}{c}0.282 * * * \\
(0.060)\end{array}$ & $\begin{array}{c}0.791^{* * *} \\
(0.069)\end{array}$ & $\begin{array}{c}0.288^{* * *} * \\
(0.059)\end{array}$ & $\begin{array}{c}0.773 * * * \\
(0.072)\end{array}$ & $\begin{array}{c}0.287 * * * \\
(0.058)\end{array}$ \\
\hline Born in China & $\begin{array}{c}-0.753^{* * *} \\
(0.062)\end{array}$ & $\begin{array}{c}-0.569 * * * \\
(0.045)\end{array}$ & $\begin{array}{c}-0.752^{* * *} \\
(0.061)\end{array}$ & $\begin{array}{c}-0.561^{* * *} \\
(0.045)\end{array}$ & $\begin{array}{c}-0.901^{* * *} \\
(0.063)\end{array}$ & $\begin{array}{c}-0.488 * * * \\
(0.043)\end{array}$ \\
\hline Born post one child & $\begin{array}{c}-0.587 * * * \\
(0.043)\end{array}$ & $\begin{array}{c}0.045 \\
(0.032)\end{array}$ & $\begin{array}{c}-0.219^{*} \\
(0.117)\end{array}$ & $\begin{array}{c}-0.162^{* *} \\
(0.074)\end{array}$ & $\begin{array}{l}-0.188^{*} \\
(0.113)\end{array}$ & $\begin{array}{c}-0.139 * * \\
(0.071)\end{array}$ \\
\hline Age & & & $\begin{array}{c}0.373^{* * *} \\
(0.064)\end{array}$ & $\begin{array}{c}0.442 * * * \\
(0.054)\end{array}$ & $\begin{array}{c}0.351^{* * *} \\
(0.064)\end{array}$ & $\begin{array}{c}0.522 * * * \\
(0.054)\end{array}$ \\
\hline Age squared & & & $\begin{array}{c}-0.005^{* * *} \\
(0.001)\end{array}$ & $\begin{array}{c}-0.007 * * * \\
(0.001)\end{array}$ & $\begin{array}{c}-0.005^{* * *} \\
(0.001)\end{array}$ & $\begin{array}{c}-0.008 * * * \\
(0.001)\end{array}$ \\
\hline Years in the United States & & & & & $\begin{array}{c}-0.024 * * * \\
(0.003)\end{array}$ & $\begin{array}{c}0.013^{* * *} \\
(0.003)\end{array}$ \\
\hline Not U.S. citizen & & & & & $\begin{array}{l}-0.019 \\
(0.053)\end{array}$ & $\begin{array}{c}-0.231 * * * \\
(0.051)\end{array}$ \\
\hline Married & & & & & $\begin{array}{c}0.259 * * * \\
(0.041)\end{array}$ & $\begin{array}{c}-0.284 * * * \\
(0.040)\end{array}$ \\
\hline Separated/divorced or widowed & & & & & $\begin{array}{c}-0.801^{* * *} \\
(0.128)\end{array}$ & $\begin{array}{c}-0.838 * * * \\
(0.094)\end{array}$ \\
\hline Constant & $\begin{array}{c}15.582 * * * \\
(0.033)\end{array}$ & $\begin{array}{c}15.276 * * * \\
(0.027)\end{array}$ & $\begin{array}{c}8.885^{* * *} \\
(1.031)\end{array}$ & $\begin{array}{c}8.734 * * * \\
(0.844)\end{array}$ & $\begin{array}{c}9.455^{* * *} \\
(1.038)\end{array}$ & $\begin{array}{c}7.369 * * * \\
(0.853)\end{array}$ \\
\hline Observations & 11,922 & 15,979 & 11,922 & 15,979 & 11,922 & 15,979 \\
\hline R-squared & 0.018 & 0.012 & 0.022 & 0.017 & 0.041 & 0.025 \\
\hline
\end{tabular}

Bootstrapped standard errors in parentheses. Dependent variable is years of education.

Observations during the Later, Longer, Fewer policy period, born between 1976 and 1979, are deleted from this sample.

$$
* * * \mathrm{p}<0.01, * * \mathrm{p}<0.05, * \mathrm{p}<0.1
$$


Table 7. Determinants of Education - China versus other East Asian Countries: Accounting for the Cultural Revolution

\begin{tabular}{|c|c|c|c|c|c|c|}
\hline VARIABLES & $\begin{array}{c}(1) \\
\text { males }\end{array}$ & $\begin{array}{c}(2) \\
\text { females }\end{array}$ & $\begin{array}{c}(3) \\
\text { Males } \\
\end{array}$ & $\begin{array}{c}\text { (4) } \\
\text { females }\end{array}$ & $\begin{array}{c}(5) \\
\text { males } \\
\end{array}$ & $\begin{array}{c}\text { (6) } \\
\text { females }\end{array}$ \\
\hline Born post-OCP * Born in China & $\begin{array}{c}0.750 * * * \\
(0.073)\end{array}$ & $\begin{array}{c}0.260 * * * \\
(0.063)\end{array}$ & $\begin{array}{c}0.790 * * * \\
(0.072)\end{array}$ & $\begin{array}{c}0.268 * * * \\
(0.063)\end{array}$ & $\begin{array}{c}0.752^{* * *} \\
(0.073)\end{array}$ & $\begin{array}{c}0.262 * * * \\
(0.062)\end{array}$ \\
\hline Born in China & $\begin{array}{c}-0.756^{* * *} \\
(0.052)\end{array}$ & $\begin{array}{c}-0.546 * * * \\
(0.042)\end{array}$ & $\begin{array}{c}-0.754 * * * \\
(0.052)\end{array}$ & $\begin{array}{c}-0.540 * * * \\
(0.042)\end{array}$ & $\begin{array}{c}-0.904 * * * \\
(0.052)\end{array}$ & $\begin{array}{c}-0.468 * * * \\
(0.043)\end{array}$ \\
\hline Born post-OCP & $\begin{array}{c}-0.611^{* * *} \\
(0.040)\end{array}$ & $\begin{array}{l}-0.040 \\
(0.038)\end{array}$ & $\begin{array}{c}-0.362 * * * \\
(0.066)\end{array}$ & $\begin{array}{c}-0.053 \\
(0.055)\end{array}$ & $\begin{array}{c}-0.308 * * * \\
(0.064)\end{array}$ & $\begin{array}{l}-0.043 \\
(0.054)\end{array}$ \\
\hline Age & & & $\begin{array}{c}0.414^{* * *} \\
(0.058)\end{array}$ & $\begin{array}{c}0.398 * * * \\
(0.049)\end{array}$ & $\begin{array}{c}0.385^{* * *} \\
(0.062)\end{array}$ & $\begin{array}{c}0.475^{* * *} \\
(0.048)\end{array}$ \\
\hline Age squared & & & $\begin{array}{c}-0.006 * * * \\
(0.001)\end{array}$ & $\begin{array}{c}-0.006 * * * \\
(0.001)\end{array}$ & $\begin{array}{c}-0.006 * * * \\
(0.001)\end{array}$ & $\begin{array}{c}-0.007 * * * \\
(0.001)\end{array}$ \\
\hline Years in the United States & & & & & $\begin{array}{c}-0.025 * * * \\
(0.003)\end{array}$ & $\begin{array}{c}0.015^{* * *} \\
(0.002)\end{array}$ \\
\hline Not U.S. citizen & & & & & $\begin{array}{l}-0.090 \\
(0.059)\end{array}$ & $\begin{array}{c}-0.303 * * * \\
(0.035)\end{array}$ \\
\hline Married & & & & & $\begin{array}{c}0.279 * * * \\
(0.039)\end{array}$ & $\begin{array}{c}-0.264^{* * *} \\
(0.041)\end{array}$ \\
\hline Separated/divorced or widowed & & & & & $\begin{array}{c}-0.785 * * * \\
(0.126)\end{array}$ & $\begin{array}{c}-0.914 * * * \\
(0.080)\end{array}$ \\
\hline Constant & $\begin{array}{c}15.607 * * * \\
(0.024)\end{array}$ & $\begin{array}{c}15.360 * * * \\
(0.020)\end{array}$ & $\begin{array}{c}8.544^{* * *} \\
(0.957)\end{array}$ & $\begin{array}{c}9.185 * * * \\
(0.807)\end{array}$ & $\begin{array}{c}9.227^{* * *} \\
(1.026)\end{array}$ & $\begin{array}{c}7.923 * * * \\
(0.789)\end{array}$ \\
\hline Observations & 14,950 & 20,329 & 14,950 & 20,329 & 14,950 & 20,329 \\
\hline R-squared & 0.021 & 0.012 & 0.024 & 0.016 & 0.048 & 0.027 \\
\hline
\end{tabular}

Bootstrapped standard errors in parentheses. Dependent variable is years of education.

Observations entering school before 1970 are deleted from this sample

$* * * \mathrm{p}<0.01, * * \mathrm{p}<0.05, * \mathrm{p}<0.1$ 
Table 8: Determinants of Education - China versus other East Asian Countries, Recent Migrants

\begin{tabular}{|c|c|c|c|c|c|c|}
\hline VARIABLES & $\begin{array}{c}(1) \\
\text { males }\end{array}$ & $\begin{array}{c}(2) \\
\text { females }\end{array}$ & $\begin{array}{c}(3) \\
\text { males }\end{array}$ & $\begin{array}{c}\text { (4) } \\
\text { females }\end{array}$ & $\begin{array}{c}(5) \\
\text { Males }\end{array}$ & $\begin{array}{c}\text { (6) } \\
\text { females }\end{array}$ \\
\hline Born post-OCP*born in China & $\begin{array}{c}0.969 * * * \\
(0.117)\end{array}$ & $\begin{array}{c}0.362 * * * \\
(0.088)\end{array}$ & $\begin{array}{c}1.050 * * * \\
(0.117)\end{array}$ & $\begin{array}{c}0.382 * * * \\
(0.087)\end{array}$ & $\begin{array}{c}0.898 * * * \\
(0.118)\end{array}$ & $\begin{array}{c}0.389 * * * \\
(0.084)\end{array}$ \\
\hline Born in China & $\begin{array}{c}-0.876 * * * \\
(0.083)\end{array}$ & $\begin{array}{c}-0.636^{* * *} \\
(0.062)\end{array}$ & $\begin{array}{c}-0.873 * * * \\
(0.083)\end{array}$ & $\begin{array}{c}-0.638 * * * \\
(0.060)\end{array}$ & $\begin{array}{c}-0.809 * * * \\
(0.081)\end{array}$ & $\begin{array}{c}-0.564 * * * \\
(0.059)\end{array}$ \\
\hline Born post-OCP & $\begin{array}{c}-0.813 * * * \\
(0.066)\end{array}$ & $\begin{array}{c}0.057 \\
(0.054)\end{array}$ & $\begin{array}{c}-0.492 * * * \\
(0.105)\end{array}$ & $\begin{array}{c}-0.118 * \\
(0.071)\end{array}$ & $\begin{array}{c}-0.400^{* * *} \\
(0.104)\end{array}$ & $\begin{array}{c}-0.117 * \\
(0.071)\end{array}$ \\
\hline Age & & & $\begin{array}{c}0.973 * * * \\
(0.088)\end{array}$ & $\begin{array}{c}0.649 * * * \\
(0.076)\end{array}$ & $\begin{array}{c}0.875^{* * *} * \\
(0.091)\end{array}$ & $\begin{array}{c}0.784^{* * *} * \\
(0.080)\end{array}$ \\
\hline Age squared & & & $\begin{array}{c}-0.015^{* * * *} \\
(0.001)\end{array}$ & $\begin{array}{c}-0.011 * * * \\
(0.001)\end{array}$ & $\begin{array}{c}-0.013^{* * *} \\
(0.001)\end{array}$ & $\begin{array}{c}-0.012 * * * \\
(0.001)\end{array}$ \\
\hline Years in the United States & & & & & $\begin{array}{c}-0.033^{* * *} \\
(0.010)\end{array}$ & $\begin{array}{c}0.021^{* *} \\
(0.009)\end{array}$ \\
\hline Not U.S. citizen & & & & & $\begin{array}{c}-0.988^{* * *} \\
(0.108)\end{array}$ & $\begin{array}{c}-0.749 * * * \\
(0.068)\end{array}$ \\
\hline Married & & & & & $\begin{array}{c}0.288 * * * \\
(0.058)\end{array}$ & $\begin{array}{c}-0.444 * * * \\
(0.051)\end{array}$ \\
\hline Separated/divorced or widowed & & & & & $\begin{array}{c}-0.539 * * \\
(0.214)\end{array}$ & $\begin{array}{c}-0.974 * * * \\
(0.149)\end{array}$ \\
\hline Constant & $\begin{array}{c}15.966 * * * \\
(0.041)\end{array}$ & $\begin{array}{c}15.288^{* * *} \\
(0.036)\end{array}$ & $\begin{array}{c}0.143 \\
(1.441)\end{array}$ & $\begin{array}{c}5.670 * * * \\
(1.230)\end{array}$ & $\begin{array}{c}1.857 \\
(1.489)\end{array}$ & $\begin{array}{c}3.495 * * * \\
(1.279)\end{array}$ \\
\hline Observations & 6,845 & 10,252 & 6,845 & 10,252 & 6,845 & 10,252 \\
\hline R-squared & 0.025 & 0.015 & 0.045 & 0.027 & 0.068 & 0.047 \\
\hline
\end{tabular}

Bootstrapped standard errors in parentheses. Dependent variable is years of education.

Sample is restricted to immigrants who arrived in the US within the past 10 years

$$
\text { *** } \mathrm{p}<0.01, * * \mathrm{p}<0.05, * \mathrm{p}<0.1
$$


Table 9: Determinants of Education - China versus other East Asian Countries, Individuals who migrated between age 10 and 17

\begin{tabular}{|c|c|c|c|c|c|c|}
\hline VARIABLES & $\begin{array}{c}(1) \\
\text { males }\end{array}$ & $\begin{array}{c}(2) \\
\text { females }\end{array}$ & $\begin{array}{c}(3) \\
\text { males }\end{array}$ & $\begin{array}{c}\text { (4) } \\
\text { females }\end{array}$ & $\begin{array}{c}(5) \\
\text { males }\end{array}$ & $\begin{array}{c}(6) \\
\text { females }\end{array}$ \\
\hline Born post-OCP*born in China & $\begin{array}{c}0.499 * * * \\
(0.168)\end{array}$ & $\begin{array}{l}-0.106 \\
(0.129)\end{array}$ & $\begin{array}{c}0.526 * * * \\
(0.168)\end{array}$ & $\begin{array}{l}-0.086 \\
(0.131)\end{array}$ & $\begin{array}{c}0.498 * * * \\
(0.167)\end{array}$ & $\begin{array}{l}-0.056 \\
(0.128)\end{array}$ \\
\hline Born in China & $\begin{array}{c}-1.320 * * * \\
(0.104)\end{array}$ & $\begin{array}{c}-0.583 * * * \\
(0.122)\end{array}$ & $\begin{array}{c}-1.314 * * * \\
(0.102)\end{array}$ & $\begin{array}{c}-0.588 * * * \\
(0.122)\end{array}$ & $\begin{array}{c}-1.304^{* * *} \\
(0.099)\end{array}$ & $\begin{array}{c}-0.606 * * * \\
(0.127)\end{array}$ \\
\hline Born post-OCP & $\begin{array}{c}-0.452 * * * \\
(0.076)\end{array}$ & $\begin{array}{c}-0.133^{* *} \\
(0.065)\end{array}$ & $\begin{array}{c}-0.132 \\
(0.136)\end{array}$ & $\begin{array}{c}-0.000 \\
(0.127)\end{array}$ & $\begin{array}{l}-0.119 \\
(0.135)\end{array}$ & $\begin{array}{c}0.018 \\
(0.127)\end{array}$ \\
\hline Age & & & $\begin{array}{c}0.240 * * \\
(0.109)\end{array}$ & $\begin{array}{c}0.333 * * * \\
(0.128)\end{array}$ & $\begin{array}{c}0.142 \\
(0.110)\end{array}$ & $\begin{array}{c}0.330 * * \\
(0.133)\end{array}$ \\
\hline Age squared & & & $\begin{array}{c}-0.003 * \\
(0.002)\end{array}$ & $\begin{array}{c}-0.005^{* * *} \\
(0.002)\end{array}$ & $\begin{array}{c}-0.003^{* *} \\
(0.002)\end{array}$ & $\begin{array}{c}-0.005^{* * *} \\
(0.002)\end{array}$ \\
\hline Years in the United States & & & & & $\begin{array}{c}0.088 * * * \\
(0.017)\end{array}$ & $\begin{array}{c}0.041^{* * *} \\
(0.015)\end{array}$ \\
\hline Not U.S. citizen & & & & & $\begin{array}{c}0.705^{* * *} \\
(0.097)\end{array}$ & $\begin{array}{c}0.389 * * * \\
(0.095)\end{array}$ \\
\hline Married & & & & & $\begin{array}{c}0.031 \\
(0.089)\end{array}$ & $\begin{array}{c}-0.332 * * * \\
(0.086)\end{array}$ \\
\hline Separated/divorced or widowed & & & & & $\begin{array}{c}-0.957 * * * \\
(0.219)\end{array}$ & $\begin{array}{c}-0.813^{* * * *} \\
(0.173)\end{array}$ \\
\hline Constant & $\begin{array}{c}15.370 * * * \\
(0.048)\end{array}$ & $\begin{array}{c}15.451^{* * *} \\
(0.048)\end{array}$ & $\begin{array}{c}10.864 * * * \\
(1.810)\end{array}$ & $\begin{array}{c}9.979 * * * \\
(2.130)\end{array}$ & $\begin{array}{c}11.908^{* * *} \\
(1.830)\end{array}$ & $\begin{array}{c}9.696 * * * \\
(2.210)\end{array}$ \\
\hline Observations & 3,036 & 3,148 & 3,036 & 3,148 & 3,036 & 3,148 \\
\hline R-squared & 0.070 & 0.031 & 0.073 & 0.034 & 0.112 & 0.057 \\
\hline
\end{tabular}

Bootstrapped standard errors in parentheses. Dependent variable is years of education. Sample is restricted to individuals who arrived in the US between the ages of 10 and 17 *** $\mathrm{p}<0.01, * * \mathrm{p}<0.05, * \mathrm{p}<0.1$ 
Table 10: Determinants of Education - China versus Other East Asian Countries: Falsified Policy Timing

\begin{tabular}{|c|c|c|c|c|c|c|}
\hline VARIABLES & $\begin{array}{c}1) \\
\text { males }\end{array}$ & $\begin{array}{c}\text { (2) } \\
\text { females }\end{array}$ & $\begin{array}{c}(3) \\
\text { males }\end{array}$ & $\begin{array}{c}\text { (4) } \\
\text { females } \\
\end{array}$ & $\begin{array}{c}(5) \\
\text { males }\end{array}$ & $\begin{array}{c}\text { (6) } \\
\text { females } \\
\end{array}$ \\
\hline Born Post-1969 * Born in China & $\begin{array}{l}-0.081 \\
(0.089)\end{array}$ & $\begin{array}{l}-0.017 \\
(0.073)\end{array}$ & $\begin{array}{l}-0.077 \\
(0.090)\end{array}$ & $\begin{array}{c}0.004 \\
(0.071)\end{array}$ & $\begin{array}{c}-0.084 \\
(0.089)\end{array}$ & $\begin{array}{l}-0.000 \\
(0.070)\end{array}$ \\
\hline Born in China & $\begin{array}{c}-0.701^{* * *} \\
(0.054)\end{array}$ & $\begin{array}{c}-0.571^{* * *} \\
(0.044)\end{array}$ & $\begin{array}{c}-0.704^{* * *} \\
(0.054)\end{array}$ & $\begin{array}{c}-0.587^{* * *} \\
(0.044)\end{array}$ & $\begin{array}{c}-0.792^{* * *} \\
(0.051)\end{array}$ & $\begin{array}{c}-0.513 * * * \\
(0.044)\end{array}$ \\
\hline Born Post-1969 & $\begin{array}{c}0.274 * * * \\
(0.052)\end{array}$ & $\begin{array}{c}0.545^{* * *} \\
(0.040)\end{array}$ & $\begin{array}{c}0.001 \\
(0.089)\end{array}$ & $\begin{array}{c}0.013 \\
(0.085)\end{array}$ & $\begin{array}{c}0.015 \\
(0.087)\end{array}$ & $\begin{array}{c}0.003 \\
(0.083)\end{array}$ \\
\hline Age & & & $\begin{array}{c}0.246 * * \\
(0.120)\end{array}$ & $\begin{array}{c}-0.030 \\
(0.140)\end{array}$ & $\begin{array}{l}0.199 * \\
(0.116)\end{array}$ & $\begin{array}{l}-0.047 \\
(0.140)\end{array}$ \\
\hline Age squared & & & $\begin{array}{c}-0.003^{* *} \\
(0.001)\end{array}$ & $\begin{array}{c}-0.001 \\
(0.002)\end{array}$ & $\begin{array}{c}-0.003^{* *} \\
(0.001)\end{array}$ & $\begin{array}{l}-0.000 \\
(0.002)\end{array}$ \\
\hline Years in the United States & & & & & $\begin{array}{c}-0.019 * * * \\
(0.002)\end{array}$ & $\begin{array}{c}0.014^{* * *} \\
(0.002)\end{array}$ \\
\hline Not U.S. citizen & & & & & $\begin{array}{c}0.545^{* * * *} \\
(0.063)\end{array}$ & $\begin{array}{c}0.258 * * * \\
(0.038)\end{array}$ \\
\hline Married & & & & & $\begin{array}{c}0.594 * * * \\
(0.070)\end{array}$ & $\begin{array}{c}0.025 \\
(0.061)\end{array}$ \\
\hline Separated/divorced or widowed & & & & & $\begin{array}{c}-0.397 * * * \\
(0.116)\end{array}$ & $\begin{array}{c}-0.492 * * * \\
(0.073)\end{array}$ \\
\hline Constant & $\begin{array}{c}15.266^{* * *} \\
(0.029)\end{array}$ & $\begin{array}{c}14.670^{* * *} \\
(0.022)\end{array}$ & $\begin{array}{c}11.030 * * * \\
(2.711)\end{array}$ & $\begin{array}{c}17.239 * * * \\
(3.157)\end{array}$ & $\begin{array}{c}11.678 * * * \\
(2.632)\end{array}$ & $\begin{array}{c}17.439 * * * \\
(3.154)\end{array}$ \\
\hline Observations & 15,526 & 21,558 & 15,526 & 21,558 & 15,526 & 21,558 \\
\hline R-squared & 0.023 & 0.024 & 0.026 & 0.031 & 0.046 & 0.044 \\
\hline
\end{tabular}

Bootstrapped standard errors in parentheses. Dependent variable is years of education.

Sample is restricted to those born before 1974 and under the age of 50 at the time of the survey. Estimates represent the effect of a 'false' OCP in 1969.

$* * * \mathrm{p}<0.01, * * \mathrm{p}<0.05, * \mathrm{p}<0.1$ 
Table 11: Determinants of Education - India versus other East Asian Countries: Falsified Treatment

\begin{tabular}{|c|c|c|c|c|c|c|}
\hline VARIABLES & $\begin{array}{c}(1) \\
\text { males }\end{array}$ & $\begin{array}{c}(2) \\
\text { females }\end{array}$ & $\begin{array}{c}(3) \\
\text { males } \\
\end{array}$ & $\begin{array}{c}\text { (4) } \\
\text { females }\end{array}$ & $\begin{array}{c}(5) \\
\text { males }\end{array}$ & $\begin{array}{c}\text { (6) } \\
\text { females }\end{array}$ \\
\hline Born Post-OCP * Born in India & $\begin{array}{c}0.428 * * * \\
(0.047)\end{array}$ & $\begin{array}{c}0.083 * * \\
(0.041)\end{array}$ & $\begin{array}{c}0.412 * * * \\
(0.048)\end{array}$ & $\begin{array}{c}0.097 * * \\
(0.040)\end{array}$ & $\begin{array}{c}0.374 * * * \\
(0.047)\end{array}$ & $\begin{array}{c}0.107 * * * \\
(0.040)\end{array}$ \\
\hline Born in India & $\begin{array}{c}0.517 * * * \\
(0.030)\end{array}$ & $\begin{array}{c}0.522 * * * \\
(0.026)\end{array}$ & $\begin{array}{c}0.507 * * * \\
(0.030)\end{array}$ & $\begin{array}{c}0.488 * * * \\
(0.027)\end{array}$ & $\begin{array}{c}0.110^{* * *} \\
(0.029)\end{array}$ & $\begin{array}{c}0.371^{* * *} \\
(0.030)\end{array}$ \\
\hline Born post-OCP & $\begin{array}{c}-0.610 * * * \\
(0.040)\end{array}$ & $\begin{array}{c}-0.023 \\
(0.030)\end{array}$ & $\begin{array}{c}-0.224^{* * *} \\
(0.054)\end{array}$ & $\begin{array}{c}0.069 \\
(0.042)\end{array}$ & $\begin{array}{c}-0.156 * * * \\
(0.053)\end{array}$ & $\begin{array}{c}0.074^{*} \\
(0.042)\end{array}$ \\
\hline Age & & & $\begin{array}{c}0.567 * * * \\
(0.040)\end{array}$ & $\begin{array}{c}0.566 * * * \\
(0.038)\end{array}$ & $\begin{array}{c}0.392 * * * \\
(0.040)\end{array}$ & $\begin{array}{c}0.451 * * * \\
(0.038)\end{array}$ \\
\hline Age squared & & & $\begin{array}{c}-0.008^{* * *} \\
(0.001)\end{array}$ & $\begin{array}{c}-0.009 * * * \\
(0.001)\end{array}$ & $\begin{array}{c}-0.006 * * * \\
(0.001)\end{array}$ & $\begin{array}{c}-0.007 * * * \\
(0.001)\end{array}$ \\
\hline Years in the United States & & & & & $\begin{array}{c}-0.020 * * * \\
(0.002)\end{array}$ & $\begin{array}{c}-0.006^{* * * *} \\
(0.002)\end{array}$ \\
\hline Not U.S. citizen & & & & & $\begin{array}{c}-0.393 * * * \\
(0.033)\end{array}$ & $\begin{array}{c}-0.301^{* * *} \\
(0.029)\end{array}$ \\
\hline Married & & & & & $\begin{array}{c}0.044 \\
(0.031)\end{array}$ & $\begin{array}{c}-0.007 \\
(0.028)\end{array}$ \\
\hline Separated/divorced or widowed & & & & & $\begin{array}{c}-0.621 * * * \\
(0.103)\end{array}$ & $\begin{array}{c}-0.792 * * * \\
(0.073)\end{array}$ \\
\hline Total Personal Income 1000's 2012\$ & & & & & $\begin{array}{c}0.000 * * * \\
(0.000)\end{array}$ & $\begin{array}{c}0.000 * * * \\
(0.000)\end{array}$ \\
\hline Constant & $\begin{array}{c}15.605^{* * * *} \\
(0.027)\end{array}$ & $\begin{array}{c}15.344 * * * \\
(0.018)\end{array}$ & $\begin{array}{c}5.823^{* * * *} \\
(0.681)\end{array}$ & $\begin{array}{c}6.274^{* * *} \\
(0.649)\end{array}$ & $\begin{array}{c}8.982 * * * \\
(0.681)\end{array}$ & $\begin{array}{c}8.101 * * * \\
(0.647)\end{array}$ \\
\hline Observations & 22,341 & 25,749 & 22,341 & 25,749 & 22,341 & 25,749 \\
\hline R-squared & 0.051 & 0.027 & 0.061 & 0.037 & 0.168 & 0.102 \\
\hline
\end{tabular}

Bootstrapped standard errors in parentheses. Dependent variable is years of education. East Asia includes S. Korea, Hong Kong,

Taiwan and Japan. Chinese migrants are dropped from the sample. Migrants from India are now the treated group.

$$
\text { *** } \mathrm{p}<0.01,{ }^{* *} \mathrm{p}<0.05, * \mathrm{p}<0.1
$$


Table 12: Determinants of Education - China versus India: India as Control

\begin{tabular}{|c|c|c|c|c|c|c|}
\hline VARIABLES & $\begin{array}{c}(1) \\
\text { males }\end{array}$ & $\begin{array}{c}(2) \\
\text { females }\end{array}$ & $\begin{array}{c}(3) \\
\text { males } \\
\end{array}$ & $\begin{array}{c}(4) \\
\text { females }\end{array}$ & $\begin{array}{c}(5) \\
\text { males }\end{array}$ & $\begin{array}{c}(6) \\
\text { females } \\
\end{array}$ \\
\hline Born post-OCP*Born in China & $\begin{array}{c}0.317 * * * \\
(0.070)\end{array}$ & $\begin{array}{c}0.180 * * * \\
(0.062)\end{array}$ & $\begin{array}{c}0.346^{* * *} \\
(0.070)\end{array}$ & $\begin{array}{c}0.143 * * \\
(0.062)\end{array}$ & $\begin{array}{c}0.368 * * * \\
(0.065)\end{array}$ & $\begin{array}{c}0.138^{* *} \\
(0.064)\end{array}$ \\
\hline Born in China & $\begin{array}{c}-1.267^{* * *} \\
(0.048)\end{array}$ & $\begin{array}{c}-1.070^{* * *} \\
(0.041)\end{array}$ & $\begin{array}{c}-1.250^{* * *} \\
(0.047)\end{array}$ & $\begin{array}{c}-1.017 * * * \\
(0.040)\end{array}$ & $\begin{array}{c}-1.172^{* * *} \\
(0.047)\end{array}$ & $\begin{array}{c}-1.036^{* * *} \\
(0.039)\end{array}$ \\
\hline Born post-OCP & $\begin{array}{c}-0.181^{* * *} \\
(0.029)\end{array}$ & $\begin{array}{c}0.059 * * \\
(0.027)\end{array}$ & $\begin{array}{l}-0.045 \\
(0.044)\end{array}$ & $\begin{array}{c}-0.084^{* *} \\
(0.041)\end{array}$ & $\begin{array}{l}-0.046 \\
(0.043)\end{array}$ & $\begin{array}{c}-0.081^{* *} \\
(0.039)\end{array}$ \\
\hline Age & & & $\begin{array}{c}0.364 * * * \\
(0.051)\end{array}$ & $\begin{array}{c}0.367 * * * \\
(0.052)\end{array}$ & $\begin{array}{c}0.255^{* * *} \\
(0.054)\end{array}$ & $\begin{array}{c}0.372 * * * \\
(0.051)\end{array}$ \\
\hline Age squared & & & $\begin{array}{c}-0.005^{* * *} \\
(0.001)\end{array}$ & $\begin{array}{c}-0.006 * * * \\
(0.001)\end{array}$ & $\begin{array}{c}-0.004 * * * \\
(0.001)\end{array}$ & $\begin{array}{c}-0.006^{* * *} \\
(0.001)\end{array}$ \\
\hline Years in the United States & & & & & $\begin{array}{c}-0.016 * * * \\
(0.003)\end{array}$ & $\begin{array}{c}0.015^{* * *} \\
(0.003)\end{array}$ \\
\hline Not U.S. citizen & & & & & $\begin{array}{c}-0.578 * * * \\
(0.043)\end{array}$ & $\begin{array}{c}-0.632 * * * \\
(0.039)\end{array}$ \\
\hline Married & & & & & $\begin{array}{c}0.136 * * * \\
(0.049)\end{array}$ & $\begin{array}{c}-0.250 * * * \\
(0.044)\end{array}$ \\
\hline Separated/divorced or widowed & & & & & $\begin{array}{c}-0.849 * * * \\
(0.117)\end{array}$ & $\begin{array}{c}-0.785^{* * *} \\
(0.095)\end{array}$ \\
\hline Constant & $\begin{array}{c}16.122 * * * \\
(0.017)\end{array}$ & $\begin{array}{c}15.866 * * * \\
(0.020)\end{array}$ & $\begin{array}{c}10.099 * * * \\
(0.838)\end{array}$ & $\begin{array}{c}10.530 * * * \\
(0.838)\end{array}$ & $\begin{array}{c}11.827 * * * \\
(0.875)\end{array}$ & $\begin{array}{c}10.520 * * * \\
(0.813)\end{array}$ \\
\hline Observations & 20,619 & 22,335 & 20,619 & 22,335 & 20,619 & 22,335 \\
\hline R-squared & 0.071 & 0.056 & 0.073 & 0.062 & 0.108 & 0.079 \\
\hline
\end{tabular}

Bootstrapped standard errors in parentheses.

Other East Asian immigrants are dropped from the sample.

*** $\mathrm{p}<0.01,{ }^{* *} \mathrm{p}<0.05,{ }^{*} \mathrm{p}<0.1$ 